\title{
THE USE OF NON-MILITARY ELEMENTS OF STATECRAFT BY CHINA DURING CAMBODIAN CRISIS 1997
}

\author{
Witjaksono
}

\begin{abstract}
Abstrak
Rekognisi atas kedaulatan suatu negara merupakan bagian dari kebijakan luar negeri yang dalam decision making process-nya pasti mempertimbangkan cost dan benefit. Proses mempertimbangkan kebijakan luar negeri akan semakin sulit dilakukan apabila rekognisi atas kedaulatan tersebut dilakukan terhadap negara yang sedang mengalami krisis. Saat Kamboja mengalami krisis pada tahun 1997, Tiongkok mengambil langkah strategis dengan memberikan rekognisi terhadap kedaulatan Kamboja. Walaupun Tiongkok memberikan rekognisi dalam bentuk yang tidak empiris, dalam hal ini elemen-elemen non-militer, namun terbukti bahwa bentuk rekognisi semacam itu sudah cukup untuk memberikan dampak berupa keuntungan strategis terhadap kedua negara khususnya Kamboja sebagai negara yang sedang mengalami krisis. Penelitian ini akan menggambarkan best practices dari upaya sebuah negara dalam memberikan rekognisi atas kedaulatan negara lain, melalui elemen-elemen yang bersifat non militer. Pada akhirnya, penggunaan elemen-elemen non-militer merupakan hal yang berpotensi dalam memberikan dampak strategis terhadap rekognisi yang dilakukan bagi negara yang sedang mengalami krisis.
\end{abstract}

Kata kunci : Elemen-elemen non-militer, Tiongkok, krisis Kamboja.

\section{Introduction}

In the aftermath of the July 1997 "coup" in Phnom Penh that ousted the Cambodian first prime minister Norodom Ranariddh, the only country that recognized both the Royal kingdom and the Royal Governement of Cambodia was the people's Republic of China. Prior to the coup, the Royal Governmement of Cambodia had been a unique coalition government headed by two prime ministers.

On Tuesday, July 8 8h $^{\text {th }} 1997$ Phnom Penh's non profit independence newspaper, the Cambodia Daily, printed a Chinese Embassy statement recognizing the Royal Government of Cambodia led solely by the Second Prime Minister Hun Sen (Witjaksono, 1997).

With the first Prime Minister Norodom Ranariddh in exile, not all embassies in Phnom Penh were as quick to make public their diplomatic 
statement as China's Embassy. In the following days the internasional reactions to Hun Sen legitimacy were varied. Some governments chose to evacuate their nationals while several others suspended their development assistance to Cambodia as a rebuke to what was commonly reported as "Hun Sen's bloody seizure of power." (Curtis, 1998). On July 10, 1997 the Association of South East Asia Nation (ASEAN) foreign ministers (excluding Laos, Myanmar and Cambodia) decided to reconsider Cambodia's entry as a full member of the regional organization. After winning the 1998 election and becoming the only prime minister in the Kingdom of Cambodia, Hun Sen led the country into stability. In February 1999 Hun Sen paid an official visit to Beijing. Hun Sen obtained \$ 18.3 milion in foreign assistance guarantees and $\$ 200$ milion in no-interest loans for Infrastructure projects. China summarized that the $\$ 218.3$ milion in aid was among the highest aid they provided to any country in the world (Marks, 2000). After the July 1997 "coup" and amid the sanctions imposed on the Hun Sen Regime by other nations, China's recognition of Cambodia displayed strong diplomatic support for the government and reinforced its strategic position as the leading nation in Southeast Asia. This case study will explore how China effectively influences Cambodia using the non -military element of statecraft.

\section{The Coalition Government}

After the United Nations Transitional authority in Cambodia (UNTAC) election, the Royal Government of Cambodia was formally established in November 1993 with FUNCINPEC (Front Uni National pour un Cambodge Independant, Neutre, Pacifique, et Cooperatif, which translates to : National United Front for an Independent, Neutral, Peaceful, and Cooperative Cambodia) led by Prince Norodom Ranariddh as the first prime minister and CPP (Cambodian Peoples Party) led by Hun Sen as the second prime minister, and co-ministers from both parties headed by the Ministries of Defense and Interior/National Security. Other co-ministerial portfolios were divided between FUNCINPEC and the CPP, with one ministry (Information 
and culture) allocated to the Buddhist Liberal Democratic Party (BLDP) (Curtis, 1998). The real controller of the offices was the CPP.

\section{The Sweeping Operation}

On Saturday, July 4, 1997, the CPP Major General Ek Sarath informed some Defense Attache's offices that on the $5^{\text {th }}$ of July the Royal Cambodian Armed Forces (RCAF) was going to launch a sweep operation in Phnom Penh. The operation objective, as he explained, was to cleanse the city from Khmer Rouge element who were welcomed by the unilateral FUNCINPEC's ranariddh policy. On July 5, 1997 a C-130 belonging to the Indonesian airforce was on the way from Bangkok to Pochentong airport in Phnom Penh carrying 30 Indonesian National Police trainers and recruits personnel. The $\mathrm{C}-130$ was about to land when the tower control ordered the incoming flight to make a turn back and seek an alternative airport in the province.

The Pochentong civilian and military airport had been attacked by FUNCINPEC General Nhek Bun Chhay's troops. The attack on Pochentong airport was General Nhek Bun Chhay's pre-emptive strike against Hun Sen's sweep operation. The battle eventually reached Ranariddh;s residence located just behind the Indonesian Defence Attache's Office and involved infantry, tanks, armored personnel carriers, and mortars that terrorized Phnom Penh's one milion residents. Ranarridh was out of the country, and he did not return until nearly a year later. Following the fighting, Hun Sen claimed that Taiwan had been covertly supporting the FUNCIPEC forces, and he promptly expelled Taiwan's unofficial liaison officers from Phnom Penh (Marks, 2000).

\section{China-Cambodia Relationship}

On May 22, 1992 two UNTAC soldiers from a Chinese Engineer Detachment were killed and seven other wounded in Kompong Thom province as a result of Khmer Rouge (KR)'s shelling. This attack marked the first bitter experience in the relationship between the KR and China as a 
traditional KR's supporter. China also noted that the KR no longer maintained its loyalty toward China since the 5-6 July crisis after a secret triangle relationship between Taiwan- Ranarridh loyalist troops and an exKhmer Rouge soldier.

"Hun sen wrote in a 1988 essay that China was the root of all was evil in Cambodia. But Just a Cambodia and Cambodians are demonstrating an almost unfathomable capacity to let bygones be bygones with regard to the former khmer Rouge, Hun Sen has now buried the past and embracing China, which he sees as a means of bringing economic development to Cambodia" (Marks, 2000).

\section{The 5-6 July "Coup"}

The UN Initiative to stabilize Cambodia by installing two Prime Ministers failed because the power sharing arrangement did not result in equal power for both. Within the first three years after election the coalition government succeeded in maintaining national security throughout Cambodia. For the first time the new RCAF that consisted of three different warring factions had fought tohether against the Khmer Rouge. But when the second prime minister Hun Sen inaugurated the 911 Commando Regiment on November 9th 1999 a new problem arose. The coalition system didn't work at all with these elitetroops since the leadership of the regiment was always tied to CPP generals. The coalition agreed to extend the power sharing up to the district level, resulting in two chiefs of district in remote areas. But this division was hard to apply because actual administrative control was in the hands of the CPP. The power sharing arrangement didn't translate to equal power control. The physical outlook for the coalition government was far from credible, especially for FUNCINPEC. Having recently re-entered Phnom Penh after 30 years fighting, that exhausted Cambodia's revenue, every minister and general was forced to be creative in funding their efforts. The common and easy means for generating revenue was by selling Cambodian natural resouces. Each side multed some foreign investors to create business concessions in mining and forestry. The Cambodia conflict eventually became a proxy competition between China and Taiwan. The existence of Taiwan's unofficial liaison office in Phnom 
Penh was not as popular as before it had been expelled by Hun Sen. But in the business arena, the Taiwanase, the Chinese and some other ASEAN countries businessmen were brutally competing to obtain Cambodia's mining and foresty concessions.

The Chinese and Taiwanese businessmen had become the prominent lobbyists that bridged the gap inside the coalition government. FUNCINPEC generals used the huge profits that resulted from the business competition to fortify their troops with brand new weaponry. FUNCINPEC troops guarded mining and foresty resources that formed the basis of funding and allowed them to maintain parity with CPP troops. As a result Hun Sen's claim Taiwan had been covertly supporting FUNCINPEC's forces was no longer questioned.

\section{Aftermath of 5-6 July "Coup"}

Amid the sanctions, Hun Sen's quick action to stabilize Cambodia convinced the international communities to begun accepting Hun Sen's power grab as a fait accompli. With only China's recognition in hand but armed with a strong personality and a talent for rhetoric, Hun Sen declared eight rules to restore the security and to stabilize Cambodia. These eight rules included forbidding embassy vehicles to apply dark tint to glass windows. Hun Sen's intelligence had discovered that some unfriendly embassies were hosting Ranariddh's loyalist when the 5-6 July crisis broke out. Hun Sen also removed illegal military men from some check points who frequently exorted money. He also convinced the international human rights tribunal that he did not commit human rights violations during the 5-6 July crisis. At the end of September 1997, Hun Sen's Chief of Cabinet led another delegation to China to meet with the Chinese Trade Minister and other officials to draft a memorandum of understanding on assistance for agriculture, power, fisheries, and maritime transport.

In December, China delivered 116 military cargo trucks and 70 jeeps valued at $\$ 2.8$ million in what both sides claimed was part of a deal that pre-dated the events of 5 and 6 July. At the ceremony to receive the 
vehicles, Hun Sen praised China's sympathetic attitude toward post-July Cambodia (Marks, 2000)

\section{China's Role in Cambodia}

The use of the accurate and timely non-military elements of statecraft by China during the turmoil in Cambodia in 1997 was the keystone of China's future influence in the Southeast Asia region. China utilized Sun Tzu's theories in its relationship with the Khmer people from the beginning of the history of the Kingdom of Kambu, during the Pol Pot era, and the CPP. It was Sun Tzu who emphasized the importance of soft power to defeat the adversary before it is necessary to use a weapon. China succesfully used at least three elements of non military statecraft to defeat Hun Sen, who used to hate China.

\section{Element Number 1 : Diplomatic Initiative}

Hun Sen's initiative to seek diplomatic support from the international community collided with China's ambition to be the single influential player in Cambodia. Unlike Thailand's military coups that had always received King Bhumibol Adulyadej's pardon or blessing after the coup, Hun Sen struggled to obtain recognition after the 5-6 July crisis. In an attempt to gain support, he ordered his generals to initiate a diplomatic approach by contacting ASEAN embassies in Phnom Penh.

Hun Sen's envoys had tried to persuade ASEAN nations not to leave Cambodia by guaranteeing the safety and security of diplomats and foreigners. In fact, the battle in Ranariddh's residence did not damage the diplomatic compound around it. The ASEAN reaction was disappointing to Hun Sen. On July 9, 1997 Singapore and Thailand sent their C-130's to evacuated their nationals. The publicity during the evacuation process that grossly exaggerated the level of instability and fighting in the Pochentong airport was also depressing to Hun Sen. Hun Sen knew that on July 9th, the airport was totally clear of 
Ranariddh loyalist troops. In this turmoil China's olive branch was quickly accepted by Hun Sen. Hun Sen's expulsion of the Taiwan trading office in Phnom Penh was not merely a result of the Taiwan military aid toward General NBC but also to satisfy China. Paul Mark noted : "Hun Sen's expulsion of Taiwan's liaison office endeared him to China and opened the door for Chinese diplomatic initiatives" (Marks, 2000). Chinese diplomats had approached Hun Sen needed the international support for his new government and offered Hun Sen well before he expelled Taiwan's liaison officers. China knew that Hun Sen needed the international support for his new government and offered Hun Sen full political recognition, on one condition: Taiwan's unofficial liaison office must quickly be closed. In mid-August 1997 Hun Sen and Ung Huot (the new FUNCINPEC First Prime Minister) travelled to Beijing to visit King Sihounuk. Chinese Premier Li Peng told Hun Sen and Ung Huot that China would "never interfere" in Cambodia's internal politics, and that Cambodia's problems "must be resolved by the Cambodian people." (Marks, 2000).

\section{Element Number 2 : Information}

China's move to quickly proclaim its recognition to Hun Sen was undoubtely based on accurate information provided by Chinese descendent network in Phnom Penh. Cambodia's ethnic Chinese, like other ethnic Chinese in ASEAN countries, were the elite society in terms of financial and educational achievements. Their numbers in Cambodia were not significant, but they became stronger after the Chinese government provided them with capital, both official and private. In return, the Chinese expatriates used the Cambodia's ethnic Chinese as lobbyist to bridge the gap inside the Cambodia coalition government in order to gain business concession. 


\section{Element Number 3 : Economic Support}

It is also no doubt that China's extraordinary support to Cambodian economy was a win-win solution that benefited both China and Cambodia in aftermath of the 5-6 July crisis. In 2008, the China National Chemical Engineering Group Corporation will build an oil refinery in Sihanoukville, Cambodia capable of processing 40,000 barrels a day. The refinery will likely cost more than $\$ 400$ million (www.irrawaddy.org, 2008).

\section{Conclusion}

There are always opportunities in the middle of crisis. After the July 1997 "coup" and amid the sanctions imposed in the Hun Sen regime, China's recognition of the Cambodia displayed strong diplomatic support for the new government and reinforced its strategic position as the leading nation in Southeast Asia.

The timely use of nonmilitary element of statecraft by China in the turmoil of Cambodia, 1997 was the keystone of China's future influence in the Southeast Asia region. Using a soft power approach, China successfully co-opted Hun Sen, who had hated China for decades.

\section{References}

Curtis, Grant, Cambodia Reborn?: The Transition to Democracy and Development, Washington, D.C.: Brookings Institution, 1998.

Marks, Paul, "China's Cambodia Strategy”, Parameter, Vol. 30 No. 3 (2000). www.irraqaddy.org/article.php?art_id=10382 